ELECTRONIC LETTER

\title{
Genetic and functional evaluation of an interleukin-12 polymorphism (IDDM18) in families with type 1 diabetes
}

\author{
R Bergholdt, P Ghandil, J Johannesen, O P Kristiansen, I Kockum, H Luthman, K S Rønningen, \\ J Nerup, C Julier, F Pociot
}

J Med Genet 2004;41:e39 (http://www.jmedgenet.com/cgi/content/full/41/4/e39).doi: 10.1136/jmg.2003.010454

$\mathrm{T}$ ype 1 (insulin dependent) diabetes mellitus (TIDM) [MIM 222100] is an autoimmune disease with both genetic and environmental components. The HLA region is the major genetic susceptibility region, but in addition several minor susceptibility loci have been suggested. Their identification is, however, difficult because of the complexity of the disease.

Recently, a new susceptibility locus, IDDM18 [MIM 605598], was reported and mapped to chromosome 5q31.1q33.1, close to the $I L 12 B$ gene, which encodes the p40 subunit of interleukin (IL) $12 .^{2-4}$ IL-12p40 production influences T cell response, and may therefore be important in TIDM pathogenesis. ${ }^{5}$ IL-12 drives the differentiation of $\mathrm{T}$ lymphocytes towards the Thl subset, characterised by production of cytokines leading to cell mediated immunity ${ }^{6-8}$ Furthermore, in the non-obese diabetic (NOD) mouse, IL-12 has been shown to play a primary role in TIDM induction. ${ }^{5} 910$ In addition, IL-12 is important in immune reactivity against infections, but it has been shown that in the absence of infection, IL-12 induced autoreactive $\mathrm{T}$ cell responses might predispose to self destructive immunity. ${ }^{11}{ }^{12}$ IL-12 is a disulphide linked heterodimer composed of a heavy chain of $40 \mathrm{kDa}, \mathrm{p} 40$, and a light chain of $35 \mathrm{kDa}, \mathrm{p} 35$, encoded by two separate genes. ${ }^{213}$ The gene for the p35 subunit, IL12A, is located on chromosome 3p12-q13.2. The two subunits of IL-12 are in contrast to most cytokines, which possess only one polypeptide chain. Many cell types express the p35 chain, while the p40 subunit is expressed principally by activated macrophages and $\mathrm{B}$ cells. ${ }^{2}$ The heterodimer, p70 or p75, is the biologically active IL- $12 .^{13}$

$I L 12 B$ is a candidate for IDDM18, as linkage disequilibrium is confined to a $30 \mathrm{~kb}$ region on chromosome 5, in which $I L 12 B$ is the only known gene. ${ }^{4}$ Several polymorphisms have been identified in $I L 12 B,,^{2}{ }^{14}$ of which the A allele of a $3^{\prime}$ UTR (untranslated region) single nucleotide polymorphism (C1159A SNP) showed strong linkage disequilibrium with the TIDM susceptibility locus in Australian and British diabetes families. ${ }^{4}$ Interestingly, evidence for functional significance of the 3'UTR polymorphism was found by investigating Epstein-Barr virus (EBV) transformed cell lines. ${ }^{4} \mathrm{~A}$ cell line with the genotype A/A showed significantly higher mRNA expression level than a $\mathrm{C} / \mathrm{C}$ cell line. ${ }^{4}$ In a recently undertaken Scandinavian TIDM genome scan no evidence for linkage to this region on chromosome 5 was demonstrated..$^{15}$

Confirmation of the significance of the $I L 12 B \quad 3^{\prime}$ UTR polymorphism in TIDM in other populations is important. The aims of our study were to seek confirmation of the involvement of the IL12B C1159A SNP in T1DM susceptibility in a population based Danish family collection of 337 simplex families and in a collection of 795 multinational multiplex families, as well as to evaluate its functional significance.

\section{Key points}

- The IL12B gene on chromosome $5 q 31-33$ is a candidate for IDDM18.

- In two large collections comprising 337 Danish type 1 diabetes mellitus (TIDM) simplex families and 795 European and American multiplex families, evidence of association in the presence of linkage disequilibrium of the C1159A SNP of the IL12B gene could not be confirmed.

- Typing of three adjacent microsatellites in the IL12B region and construction of haplotypes of these and the C1159A SNP did not reveal a TIDM association.

- Neither functional significance nor a significant allele dosage effect on either mRNA or protein level could be confirmed, although there was a trend $(p=0.06)$ for more IL-12 protein to be produced in the presence of the 1159 C allele.

- The data suggest interindividual differences in stimulated IL-12 expression levels, and underline the complexity of the IL-12 system.

- In conclusion, both the genetic and the functional data conflict with the original findings, and do not support the IL12B locus as a risk locus for TIDM.

\section{METHODS}

\section{Subjects}

We used DNA from 337 Danish TIDM simplex families. ${ }^{16} 17$ Their median age of onset was nine years (range 0 to 29). DNA was also used from a group of Scandinavian TIDM sibling pair (multiplex) families, consisting of 153 Danish families (comprising 166 affected sibling pairs (ASP)), 184 Swedish families (comprising 200 ASP), and 77 Norwegian families (89 ASP), ${ }^{15}$ as well as from 126 French families (158 ASP) and 255 American families (310 ASP), detailed in Nerup et al and Delepine et al. ${ }^{15} 18$

\section{Methods}

DNA was extracted from leucocytes using standard procedures $^{19}$ or prepared as PEP-DNA. ${ }^{20}$

\section{Genotyping}

For the Danish families a polymerase chain reaction (PCR) based restriction fragment length polymorphism (RFLP)

Abbreviations: ASP, affected sibling pairs; TIDM, type 1 diabetes mellitus 
assay for the C1159A SNP was established, using the following primers: 5' TTTGGAGGAAAAGTGGAAGA 3' and 5' AACATTCCATACATCCTGGC 3'. We used $12.5 \mathrm{ng}$ genomic DNA for PCR in a total volume of $20 \mu \mathrm{l}$ on a Hybaid thermal cycler. In addition, the PCR mixture contained 0.75 unit TaqGold polymerase in $1 \times$ PCR buffer (Applied Biosystems), $1 \mu \mathrm{M}$ of each primer, $50 \mu \mathrm{M} \mathrm{dNTP}, 2.5 \mathrm{mM} \mathrm{MgCl}_{2}$, and water. Denaturing, annealing, and extension temperatures of $95^{\circ}$, $60^{\circ}$, and $72^{\circ}$, respectively, for 30 seconds each in a total of 36 cycles were used, followed by a final extension at $72^{\circ}$ for 10 minutes. The resulting PCR products were digested with 5 units TaqI-enzyme (New England Biolabs, Manchester-bythe-Sea, Massachusetts, USA) for 16 hours at $65^{\circ}$ and analysed by gel electrophoresis in a $2 \%$ agarose gel. The PCR product is 323 base pairs (bp), and in the presence of a TaqI site (the $C$ allele), the product is cut into two: 185 and 138 bp. The Swedish, Norwegian, French, and American families were typed by a slightly different restriction fragment length polymorphism (RFLP) assay, using the primers: 5' GGCATTCTCTTCCAGGTTCTG $3^{\prime}$ and $5^{\prime}$ CCATGGCAACTTGAGAGCTG 3'. PCR products are 243 bp, and after TaqI digest sizes of 173 and 70 bp (allele C) or 243 bp (allele A) were obtained. Taq-polymerase from Bioline (Bioline, Springfield, New Jersey, USA) and an annealing temperature of $65^{\circ} \mathrm{C}$ were used. All other conditions were as described above.

Genotyping of the microsatellite marker D5S2941 was done by PCR amplification using a fluorescently labelled forward primer: 5' FAM-TCACCAGTGGAGATTTTCATTC 3' and the reverse primer: 5' TTGGCCTCAGTACGCTTCTT 3'. Fluorescently labelled fragments were size fractionated on automated DNA sequencing equipment ABI3100 (Applied Biosystems), according to the manufacturer's instructions, and allele calling was carried out using GeneMapper software (Applied Biosystems).

\section{Cell stimulation}

Lipopolysaccaride is a known stimulus for IL-12 production, ${ }^{21-23}$ and preincubation with interferon $\gamma$ (IFN $\gamma$ ) is known to augment IL-12 production even further. ${ }^{24}{ }^{25}$

\section{Panels A and B}

Cells from 37 individuals in total $(9+28$ individuals) were isolated. Peripheral blood mononuclear cells, $5 \times 10^{6} / \mathrm{ml}$, were stimulated with $1 \mu \mathrm{g}$ lipopolysaccharide/well, and incubated for 6 or 24 hours $\left(37^{\circ}, 5 \% \mathrm{CO}_{2}\right)$. The media contained RPMI 1640 with glutamax and $10 \%$ fetal calf serum (Gibco, Invitrogen, Carlsbad, California, USA). After incubation, cells were harvested, washed in phosphate buffered saline, and pelleted by centrifugation.

Panel C

Cells from 21 individuals were isolated and peripheral blood mononuclear cells, $1 \times 10^{6} / \mathrm{ml}$, were preincubated with 1000 units of recombinant human IFN $\gamma$ (BD Biosciences, Franklin Lakes, New Jersey, USA) per ml for 16 hours and afterwards stimulated with $1 \mu \mathrm{g}$ lipopolysaccharide/well and incubated for 30 hours $\left(37^{\circ}, 5 \% \mathrm{CO}_{2}\right)$. The media and subsequent handling were exactly as outlined above.

\section{Protein measurements}

Two commercially available enzyme linked immunosorbent assay (ELISA) kits were used (Amersham Pharmacia Biotech, Buckinghamshire, UK) according to the manufacturer's instructions, one measuring the biologically active human IL-12p70, the other measuring total IL-12(p40+p70). Absorbance was measured at $450 \mathrm{~nm}$ (ref $620 \mathrm{~nm}$ ) using an immunoreader (Spectra II SLT; Wallac, Turku, Finland). The working ranges of the assays were 15.4 to 600 and 25 to
$1000 \mathrm{pg} / \mathrm{ml}$, respectively. Sensitivity was $<3 \mathrm{pg} / \mathrm{ml}$ and $5 \mathrm{pg} /$ $\mathrm{ml}$, respectively. Supernatants were diluted to fit the working range of the assays. All samples were measured in duplicate and the mean of the two measurements was used for the data analysis.

\section{Semiquantitative reverse transcription polymerase chain reactions}

Total RNA was isolated using a TRIzol method, according to the manufacturer's instructions of the RNAzol method (Gibco, Invitrogen) with minor modifications. ${ }^{26}$ cDNA synthesis was undertaken by oligo-dT primed reverse transcription of total RNA as described by the manufacturer (TaqMan Reverse Transcription Reagents, Applied Biosystems). Quantitative PCR measuring IL-12 mRNA, with and without lipopolysaccharide stimulation, was carried out using the following primers: 5'CAGGACCGCTACTATAGCTCATC 3' and 5'AACATTCCATACATCCTGGC 3' located in exon 7 and 3'UTR, respectively, in order to avoid DNA contamination. The housekeeping gene SPl was used as internal standard for quantification, comparing transcript expression, as it was stable under the cell stimulation conditions used. The SPl primers were 5'GTATTTGACCAGAACCATCC 3' and 5'TACCTCAAAGGAACAGAGTGG 3'. These primers were included in the same PCR mixture. The mixture contained $6 \mu \mathrm{l}$ cDNA as template and $1 \times$ polymerase buffer, $50 \mu \mathrm{M}$ dNTP, $2.5 \mathrm{mM} \mathrm{MgCl}_{2}, 0.5$ and $0.2 \mu \mathrm{M}$ of each primer, 1.2 units TaqGold DNA polymerase (Applied Biosystems), 0.123 Mbeq $\alpha^{33} \mathrm{P}$ CTP, and water in a total volume of $30 \mu \mathrm{l}$. The following protocol was used: initial denaturing for 12 minutes at $96^{\circ}$, followed by denaturing, annealing, and extension temperatures of $95^{\circ}, 63^{\circ}$, and $72^{\circ}$ each for 30 seconds and repeated in 38 cycles, followed by a 10 minute final extension at $72^{\circ}$. Samples were diluted in Stop-buffer and denatured for three minutes at $95^{\circ}$, before being loaded on a preheated $6 \%$ polyacrylamide gel and run for two hours at $65 \mathrm{~W}$ in $1 \times \mathrm{TBE}$. After drying and exposure of the gel to a storage phosphor screen (Molecular Dynamics, Sunnyvale, CA, USA), the transcription products were scanned and quantified on a Taiphoon 8600 variable mode imager (Molecular Dynamics) using ImageQuant software (Molecular Dynamics) and expressed relative to the internal standard (SPl) co-amplified in each PCR reaction. As the polymorphism is located in the cDNA sequence and involves the recognition site of TaqI enzyme, it is possible to evaluate the allele specific mRNA expression on TaqI digested cDNA.

\section{Statistics}

Allele transmission patterns from heterozygous parents to all affected offspring were analysed by TDT test, ${ }^{27}$ calculating $\chi^{2}$ and the corresponding $\mathrm{p}$ value. Transmission from heterozygous parents to unaffected offspring was also analysed by $\chi^{2}$ statistics. Haplotype TDT was calculated by using Genehunter version 2.1 (UK HGMP Resource Centre). For analysing mRNA quantitative data and protein data, one way analysis of variance (ANOVA) was used for comparison. We accepted two sided $p$ values of $<0.05$ as significant.

\section{RESULTS TDT analyses}

The IL12B C1159A SNP was tested in a Danish family collection of 337 TIDM simplex families, as well as in a collection of 795 Danish, Swedish, Norwegian, French, and American multiplex families. All individuals were genotyped using a PCR based RFLP assay, including TaqI digestion and gel electrophoresis analysis. ${ }^{4}$ No deviation from the HardyWeinberg equilibrium was observed, either in parents or probands. 
No significant linkage to TIDM, in the presence of linkage disequilibrium, could be demonstrated for the 3'UTR IL12B polymorphism. In the Danish simplex families, allele A was transmitted 99 times to diabetic offspring from heterozygous parents $v 77$ transmissions of allele $C(p=0.10)$. Surprisingly, transmission of the alleles to unaffected offspring from heterozygous parents showed significantly increased transmission of allele A ( 109 transmissions, $v 65$ transmissions of allele $C(p=0.0009))$. Comparing the transmission patterns to the affected $v$ the unaffected, however, showed no significant difference $(p=0.23)$. In the collection of European and American multiplex families likewise no distorted allele transmission to affected offspring could be demonstrated ( 373 transmissions of allele A $v 413$ transmissions of allele $C(p=0.15))$. The transmission pattern to unaffected was not distorted in this sample (155 $v 163$ transmissions of allele A $v \mathrm{C}(\mathrm{p}=0.65))$ (table 1$)$.

Analyses were also done under HLA stratification in affected individuals who carry the high risk HLA genotype (DR3/4 heterozygotes) and other affected individuals (nonDR3/4 heterozygotes). There were no significant differences in HLA subgroups, either in the combined material or in the different nationalities. Data were also stratified according to age at onset, separately in affected individuals with young age at onset (before six years) or older age at onset (six years or more). Likewise, there was no significant transmission distortion in these two subgroups. TIDM association has been demonstrated for an intronic microsatellite marker D5S2941 (located in intron 1 of the IL12B gene), ${ }^{28}$ and we tested this marker in 337 Danish simplex families and the 153 Danish multiplex families. In the original study, ${ }^{28}$ only two alleles were found, whereas in two of the simplex families of the present study a third allele was demonstrated. No distorted transmission of any of the alleles in either the simplex or multiplex subgroup or in the combined material was found (table 2). Likewise, construction of haplotypes for the C1159A SNP and D5S2941 showed no TIDM association for any combination (table 3).

The Scandinavian multiplex families have previously been genotyped for two other microsatellite markers, D5S410 and D5S422, flanking the IL12B gene. ${ }^{15}$ For the current study, TDT tests including the Scandinavian multiplex families were done for these two markers in order to evaluate individual evidence for association to TIDM. For D5S410, a lower than expected transmission of allele 9 to affected offspring (213 transmissions $v 258$ non-transmissions, $\mathrm{p}=0.04$ ) and an increased transmission of allele $7(274 v 230, \mathrm{p}=0.05)$ were demonstrated. For D5S422, random transmission of all alleles was identified (data not shown). For the Scandinavian multiplex families, we therefore constructed haplotypes for the C1159A SNP and the D5S410 marker, and identified an excess transmission of a haplotype containing allele A of the
C1159A SNP and allele 4 of D5S410 (39 transmissions $v 23$ non-transmissions, $\mathrm{p}=0.04)$, but when correcting for the number of haplotypes tested this did not remain statistically significant.

For the Danish multiplex families $(n=153)$, which have been typed for all four markers, haplotypes were constructed for all the markers. One haplotype containing allele 9 of D5S410, allele A of C1159A SNP, allele 1 of D5S2941, and allele 11 of D5S422 was found transmitted five times $v 17$ nontransmissions $(p=0.01)$, but when correcting for number of haplotypes tested, this did not remain statistically significant.

\section{RT-PCR}

To evaluate a possible functional significance of the C1159A SNP, cDNA from nine genotyped individuals (three of each genotype) was prepared and a quantitative PCR assay undertaken. cDNA was prepared both from six hour lipopolysaccharide stimulated and from unstimulated peripheral blood mononuclear cells. The results from unstimulated cells showed no constitutive IL- 12 production (data not shown). In stimulated cells, no significant difference between the IL-12p40 mRNA levels of the three genotypes or allele carrier effect were demonstrated $(p=0.70)$ (fig 1 ). Results are expressed as relative expression levels, compared with an internal standard, the housekeeping gene SP1.

The cDNA was also TaqI digested in order to evaluate the levels for the $1159 \mathrm{C}$ and the 1159A allele separately after lipopolysaccharide stimulation. This showed equal levels of both alleles, thus not suggesting preferential transcription of any one allele.

\section{ELISA}

To furthermore evaluate a possible functional significance of the polymorphism on the protein level, we determined IL- 12 levels in supernatants from mononuclear cell suspensions in relation to genotype, using ELISA assays measuring both IL12 p70 and total IL-12p40+70. We initially tested 10 unstimulated cell supernatants and found no IL-12 production, indicating no constitutive expression of either total IL-12 or IL-12p70 (data not shown).

Initially the same nine individuals as above were examined, three with each genotype. Cells were stimulated with lipopolysaccharide for six hours, and total IL-12p40+p70 and IL-12p70 were measured in the supernatants. The results suggested no statistically significant allele dependent expression when the amounts of IL- $12 \mathrm{p} 40+p 70(\mathrm{p}=0.28)$ and IL$12 \mathrm{p} 70(\mathrm{p}=0.85)$ were compared among the supernatants from the $1159 \mathrm{C} / \mathrm{C}$, the $1159 \mathrm{C} / \mathrm{A}$, and $1159 \mathrm{~A} / \mathrm{A}$ genotypes (figs 2 and 3, panel A).

However, protein levels were in all cases quite low, suggesting that little protein is produced or secreted during only six hours of lipopolysaccharide stimulation. Therefore

Table 1 TDT analysis of the IL12B C1 159A SNP in 337 Danish type I diabetes simplex families, and in 795 type I diabetes multiplex families (153 Danish, 184 Swedish, 77 Norwegian, 126 French, and 255 American)

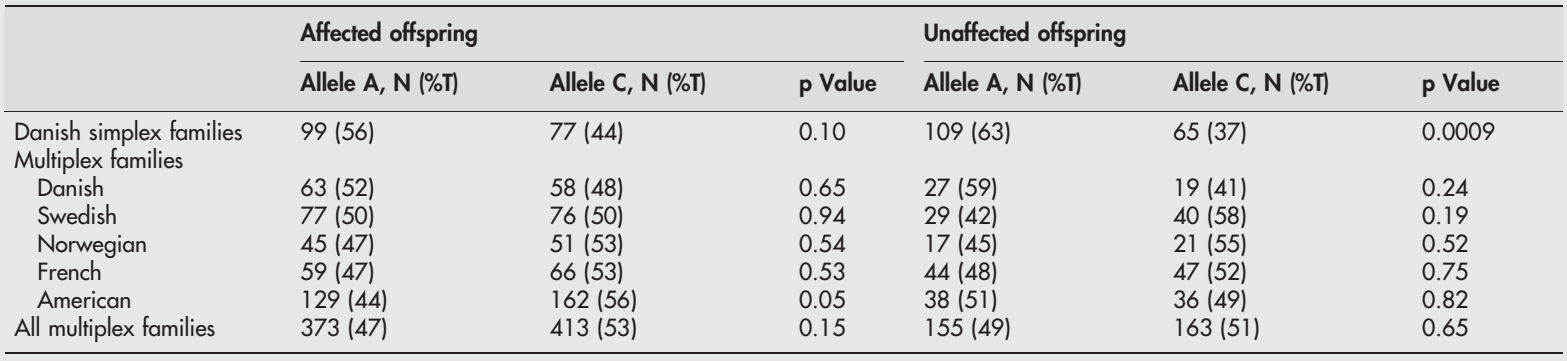

Allele transmission patterns from heterozygous parents to affected and unaffected offspring are shown; $\chi^{2}$ statistics were used and the corresponding $p$ values are shown. 
Table 2 Transmission patterns of the alleles of D5S2941, tested in 337 Danish simplex families and 153 Danish multiplex families

\begin{tabular}{|c|c|c|c|c|c|c|}
\hline \multirow[b]{2}{*}{ D5S2941 } & \multicolumn{2}{|l|}{ Allele 1} & \multicolumn{2}{|l|}{ Allele 2} & \multicolumn{2}{|l|}{ Allele 3} \\
\hline & $\begin{array}{l}\text { Transmissions } \\
(\% \mathrm{~T})\end{array}$ & $\begin{array}{l}\text { Non-transmissions } \\
(\% \text { non-T) }\end{array}$ & $\begin{array}{l}\text { Transmissions } \\
(\% \mathrm{~T})\end{array}$ & $\begin{array}{l}\text { Non-transmissions } \\
(\% \text { non- } \mathrm{T})\end{array}$ & $\begin{array}{l}\text { Transmissions } \\
(\% \mathrm{~T})\end{array}$ & $\begin{array}{l}\text { Non-transmissions } \\
\text { (\% non-T) }\end{array}$ \\
\hline Danish simplex & $79(52 \%)$ & $72(48 \%)$ & $71(47 \%)$ & $80(53 \%)$ & $2(100 \%)$ & $0(0 \%)$ \\
\hline Danish multiplex & $59(52 \%)$ & $55(48 \%)$ & 55 (48\%) & $59(52 \%)$ & - & - \\
\hline Combined & $138(52 \%)$ & $127(48 \%)$ & $126(48 \%)$ & $139(52 \%)$ & $2(100 \%)$ & $0(0 \%)$ \\
\hline
\end{tabular}

we also measured total IL-12(p40+p70) and IL-12p70 levels in 28 supernatants from a sample stimulated with lipopolysaccharide for 24 hours. Stratifying these samples according to genotype revealed the same pattern-a slight trend for more IL-12, in total and p70 alone, produced when the C allele is present, but no statistically significant support for an allele dosage effect (figs 2 and 3, panel B). Total IL$12(\mathrm{p} 40+\mathrm{p} 70)$ levels (mean (SD)) after 24 hours of lipopolysaccharide stimulation were 558 (185) $\mathrm{pg} / \mathrm{ml}$ for genotype $1159 \mathrm{~A} / \mathrm{A}(\mathrm{n}=17), 626$ (363) $\mathrm{pg} / \mathrm{ml}$ for genotype $1159 \mathrm{~A} / \mathrm{C}$ $(\mathrm{n}=10)$, and 1585 (1159) $\mathrm{pg} / \mathrm{ml}$ for genotype $1159 \mathrm{C} / \mathrm{C}$ $(\mathrm{n}=1)$.

Owing to uneven distribution of individuals with the different genotypes in this sample, and in order to increase IL-12B induction, we extended the measurements further. A new sample comprising 21 individuals, seven with each genotype, was chosen. Cells were treated according to an optimised protocol, including preincubation with IFN $\gamma$ for 16 hours, followed by stimulation with lipopolysaccharide for 30 hours to maximise IL-12 production. Equally, in this sample no statistically significant allele dosage effect was seen, although a trend $(p=0.13$ for IL- $12 p 40+p 70$ and $p=0.06$ for IL-12p70) is suggested (figs 4 and 5). Analysis of these data independent of genotype suggested interindividual differences (for panel $\mathrm{C}, \mathrm{p}<0.0001$ ). As seen from the figures, the IL-12p70 levels are much lower than the levels of total IL- 12 $(\mathrm{p} 40+\mathrm{p} 70)$, indicating that IL-12p40 is being produced in large excess compared with IL-12p70.

\section{DISCUSSION}

In two large samples-a population based Danish simplex family collection (337 families) and a collection of almost 800 European and American TIDM multiplex families-we did not find evidence of linkage in the presence of linkage disequilibrium of the C1159A SNP. No evidence for transmission disequilibrium of the 1159A allele was observed in either of these samples $(p=0.10$ and $p=0.15)$. This is in agreement with four other recent published studies, which were also not able to replicate linkage of this polymorphism to T1DM-a Norwegian, a Northern Irish, an Italian, and a multinational cohort, respectively. ${ }^{29-32}$ A fifth study did not find association of the C1159A SNP, but of a microsatellite marker, D5S2941, close to the SNP. ${ }^{28}$
Stratification by HLA type and age at onset in the present study did not reveal significant differences when correcting for the number of tests done. In addition, we examined the transmission to unaffected offspring which has not been reported by others. We found a preferential transmission of the $1159 \mathrm{~A}$ allele $(\mathrm{p}=0.0009)$ to unaffected offspring in the simplex families, but not in the multiplex families. However, the transmission pattern to affected $v$ unaffected in the simplex families was not significantly different $(p=0.23)$. The distorted transmission of the A allele to unaffected offspring in the Danish simplex families might indicate a general distortion bias in this region, as was reported in other chromosome regions. ${ }^{33}$

No evidence for linkage to TIDM was identified in the $I L 12 B$ region in the Scandinavian genome scan. ${ }^{15}$ However, D5S2941 - an intronic marker in the IL12B gene, which was found associated to TIDM by Davoodi-Semiromi et $a^{28}$ - was tested in 337 simplex and 153 multiplex families, but we were not able to confirm the original finding of linkage of D5S2941. Furthermore, in contrast to Davoodi-Semiromi's findings, ${ }^{28}$ no haplotype of the C1159A SNP or alleles of this microsatellite marker were shown linked to TIDM in the present study. We also tested the two microsatellite markers used in the Scandinavian genome scan, flanking the $I L 12 B$ locus on chromosome 5. For D5S410, allele 9 and allele 7 showed distorted transmission patterns to affected offspring; however, $\mathrm{p}$ values did not remain significant after correction for the number of alleles tested, which was also the case for a haplotype comprising allele A of C1159A SNP and allele 4 of D5S410, showing increased transmission. Haplotypes for all four markers in the region did reveal one combination that was found to be linked to TIDM, but again when correcting for the number of comparisons made, this did not remain significant. Although none of these microsatellite markers is likely to be causal, the findings-including the TIDM association of D5S2941 reported by Davoodi-Semiromi et al, ${ }^{28}$ (though not in the present study)—suggest the existence of genetic variation in this region. Analysis of more markers in the region would be interesting but was outside the scope of the present study.

Importantly, it was originally suggested that the $I L 12 B$ C1159A SNP has functional significance, as the 1159A allele was associated with increased IL-12 mRNA expression. ${ }^{4}$ We attempted to evaluate the possible functional significance of

Table 3 Haplotypes of C1159A and D5S2941

\begin{tabular}{llll}
\hline Haplotypes C1 159A-D5S2941 & Transmissions (\% T) & $\begin{array}{l}\text { Non-transmissions } \\
\text { (\% non-T) }\end{array}$ & p Value \\
\hline Haplotype A-1 & $120(54 \%)$ & $102(46 \%)$ & 0.23 \\
Haplotype A-2 & $16(55 \%)$ & $13(45 \%)$ & 0.58 \\
Haplotype C-1 & $1(33 \%)$ & $2(67 \%)$ & 0.56 \\
Haplotype C-2 & $89(45 \%)$ & $111(55 \%)$ & 0.12 \\
Haplotype C-3 & $2(100 \%)$ & $0(0 \%)$ & 0.16 \\
\hline
\end{tabular}

Transmission of haplotypes of C1159A and D5S2941.

Corresponding $\mathrm{p}$ values are shown. 


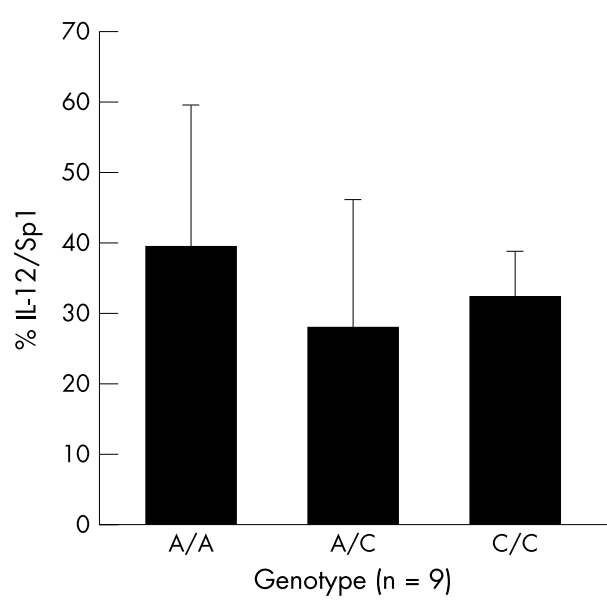

Figure 1 Quantitative polymerase chain reaction. IL-12p40 mRNA levels in relation to genotype of the IL12B C1159A SNP. Levels are expressed as relative expression, compared with an internal standard, SP1. Three individuals with each genotype were used. Error bars $=S D$.

the polymorphism on both mRNA and protein levels. The mRNA level was evaluated by means of semiquantitative PCR of cDNA from lipopolysaccharide stimulated and unstimulated human peripheral blood mononuclear cells. The protein level was examined by ELISA, measuring the levels of the biologically active IL-12p70 and total IL-12(p70+p40). We could not confirm a possible functional significance or show a significant allele dosage effect on either mRNA or protein level.

In addition to forming heterodimers with p35, the p40 subunit may also form homodimers. These p40 homodimers can compete with the p35-p40 heterodimers and thereby modulate IL-12 function. ${ }^{2}$ IL-12p40 can bind to the IL-12 receptor, but does not trigger biological activity. On the contrary, it is even believed to specifically inhibit IL-12 mediated responses. The p40 subunit is produced in large excess over IL-12p70, and has been proposed to be a natural IL-12 antagonist. ${ }^{13}$ In addition, the IL-12p40 homodimer has been shown in NOD mice to suppress diabetes development. ${ }^{34}$

Our non-significant functional results on this polymorphism are in agreement with the findings of Dahlman et al, ${ }^{29}$ whereas the trend we report for a possible allele carrier effect of the $\mathrm{C}$ allele is the same as reported by Seegers et al, ${ }^{35}$ but opposite to that originally described by Morahan et al. ${ }^{4}$ Overall, the studies of the effect of this polymorphism on IL-12B expression are not conclusive.

In relation to functional significance, the design of our studies differs in important aspects from previously published reports. ${ }^{4829}$ Two of those studies ${ }^{429}$ were done

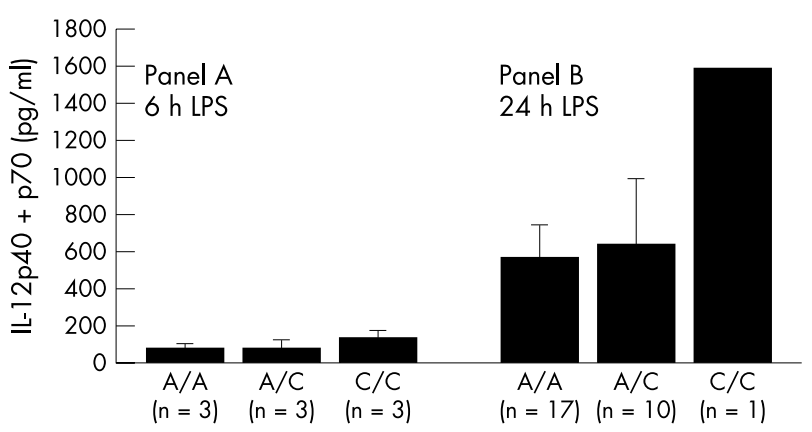

Figure 2 Lipopolysaccharide (LPS) stimulated IL-12p40+p70 protein levels. IL-12p40+p70 levels (pg/ml) after six (panel A) and 24 hours (panel B) of LPS stimulation in relation to C1159A SNP genotype. Error bars $=S D$.

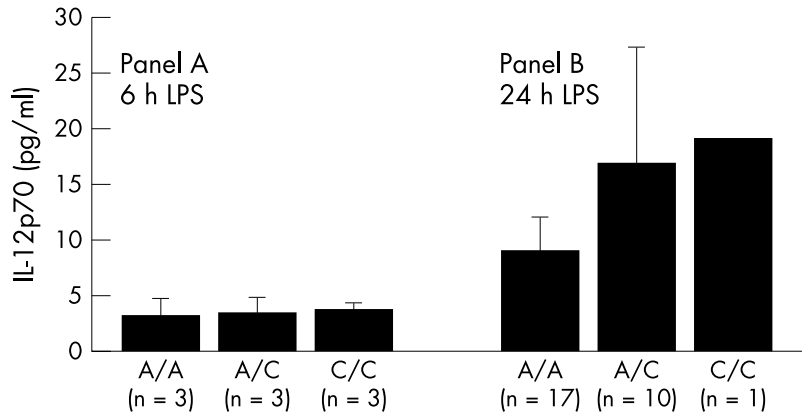

Figure 3 Lipopolysaccharide (LPS) stimulated IL-12p70 protein levels. IL-12p70 levels (pg/ml) after six (panel A) and 24 hours (panel B) of LPS stimulation in relation to C1159A SNP genotype. Error bars $=$ SD.

with EBV transformed cell lines, whereas the present study was done with mRNA from non-transformed human peripheral blood mononuclear cells. The significance of EBV transformation on IL-12 is not fully known, but EBV transformed B cells are known to produce not only IL-12 but also an IL12-like molecule. ${ }^{9}$ This molecule is composed of IL-12p35 linked to the product of a chromosome 19 locus, EB13, with $27 \%$ homology to IL-12p40. This IL-12-like molecule is probably constitutively secreted in these transformed cells, but does not inhibit IL- 12 binding to its receptor as the p40 homodimer probably does. ${ }^{9}$ This might represent a bias in evaluating IL-12 measurements from EBV transformed cells. Furthermore, these two studies ${ }^{49}$ used only unstimulated cell lines. Interestingly, in human peripheral blood mononuclear cells we could not detect any unstimulated IL-12B expression on either mRNA or protein levels. The third functional study ${ }^{28}$ used RNA extracted from peripheral blood lymphocytes after lipopolysaccharide stimulation from three heterozygous individuals for their expression studies. Their study suggested that the expression of the 1159A allele was $\approx 50 \%$ higher than that of the $1159 \mathrm{C}$ allele. We undertook a similar analysis on three heterozygous individuals without demonstrating preferential transcription of any of the alleles.

The fact that the functional protein is assembled by two subunits means that only looking at transmission patterns of the one subunit variant might not be the best approach and should be followed by functional studies. We found that the amount of p40 homodimer is much greater than the amount of IL-12p70. This might indicate that the amount of the

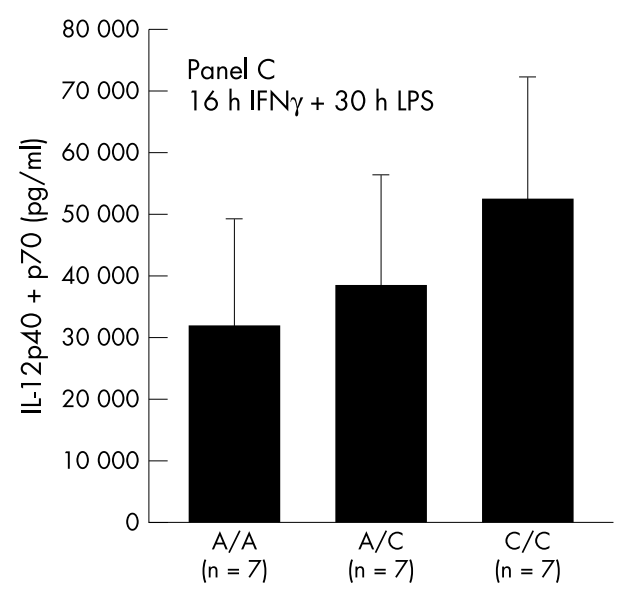

Figure 4 Interferon $\gamma$ (IFN $\gamma$ ) and lipopolysaccharide (LPS) stimulated IL$12 p 40+p 70$ protein levels. IL-12p40+p70 levels (pg/ml) after 16 hours of IFN $\gamma$ and 30 hours of LPS stimulation (panel C) in relation to C1159A SNP genotype. Error bars $=$ SD. 


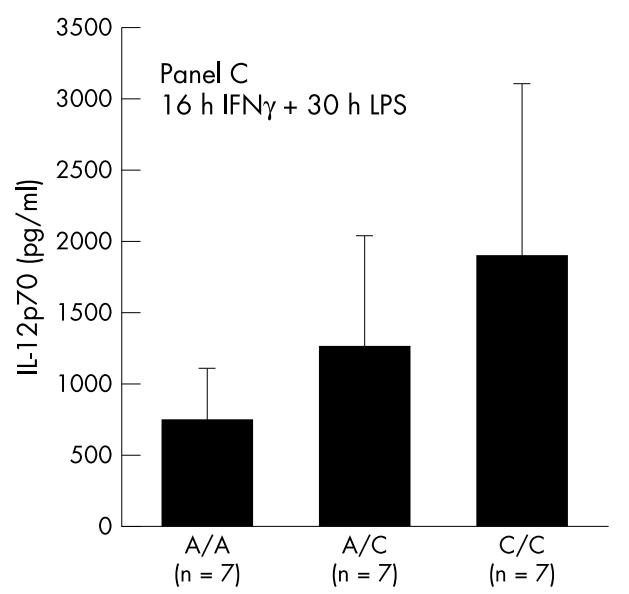

Figure 5 Interferon $\gamma$ (IFN $\gamma$ ) and lipopolysaccharide (LPS) stimulated IL12 p70 protein levels. IL-12p70 levels (pg/ml) after 16 hours of IFN $\gamma$ and 30 hours of LPS stimulation (panel C) in relation to C1159A SNP genotype. Error bars $=S D$

antagonist — the p40 homodimer, apparently produced in much greater proportion than the IL-12p70-could be very important in determining the action of IL-12. This indicates that the correlation between IL-12B mRNA and protein levels is not simple and that extrapolation from mRNA expression level to function of IL-12 molecules will certainly prove difficult.

To evaluate expression at the protein level as well we have used several stimulation protocols and a large number of individuals. They all produced consistent observations of no significant correlation between genotype and IL-12 production, although a trend for higher expression of the $1159 \mathrm{C}$ at protein level was seen, conflicting with the findings of Morahan et al. ${ }^{4}$ However, the data suggest interindividual differences in lipopolysaccharide and IFN $\gamma$ stimulated IL-12 expression levels.

\section{Conclusions}

We could not confirm T1DM association of the tested $I L 12 B$ polymorphism in large multinational cohorts. Support for disease association through functional studies-both on mRNA and protein levels_-was not achieved either.

\section{ACKNOWLEDGEMENTS}

We thank Bodil Bosmann Jørgensen and Rikke Bonne for excellent technical assistance. The Danish Study Group for Diabetes in Childhood, and the Danish IDDM Epidemiology and Genetics Group are acknowledged for their help in collection of the Danish families.

\section{Authors' affiliations}

R Bergholdt, J Johannesen, O P Kristiansen, J Nerup, F Pociot, Steno Diabetes Centre, Gentofte, Denmark

P Ghandil, C Julier, Institut Pasteur, Paris, France

I Kockum, Karolinska Institutet, Stockholm, Sweden

H Luthman, Lund University, Sweden

K S Rønningen, Norwegian Institute of Public Health, Oslo, Norway

Correspondence to: Dr F Pociot, Flemming Pociot, Steno Diabetes Centre, 2 Niels Steensensvej, DK-2820 Gentofte, Denmark; fpoc@steno.dk

Received 12 May 2003

Accepted for publication 21 August 2003

\section{REFERENCES}

1 Pociot F, McDermott MF. Genetics of type 1 diabetes mellitus. Genes Immun 2002;3:235-49.
2 Huang D Cancilla MR, Morahan G Complete primary structure, chromosomal localisation, and definition of polymorphisms of the gene encoding the human interleukin-12 p40 subunit. Genes Immun 2000;1:515-20.

3 Warrington JA, Bengtsson U. High-resolution physical mapping of human $5 q^{31-q 33}$ using 3 methods - radiation hybrid mapping, interphase fluorescence in-situ hybridization, and pulsed-field gel-electrophoresis. Genomics 1994;24:395-8.

4 Morahan G, Huang DX, Ymer SI, Cancilla MR, Stephen K, Dabadghao P, Werther G, Tait BD, Harrison LC, Colman PG. Linkage disequilibrium of a type 1 diabetes susceptibility locus with a regulatory IL12B allele. Nature Genet 2001;27:218-21.

5 Adorini L. Interleukin 12 and autoimmune diabetes. Nature Genet 2001;27:131-2.

6 Liblau RS, Singer SM, McDevitt HO. Th1 and Th2 CD4(+)T-cells in the pathogenesis of organ-specific autoimmune-diseases. Immunol Today 1995; 16:34-8.

7 Tian J, Olcott AP, Hanssen LR, Zekzer D, Middleton B, Kaufman DL. Infectious Th1 and Th2 autoimmunity in diabetes-prone mice. Immunol Rev 1998; 164:119-27.

8 Manetti R, Parronchi P, Giudizi MG, Piccinni MP, Maggi E, Trinchieri G Romagnani S. Natural-killer-cell stimulatory factor (Interleukin-12 (IL- 12)) induces T-helper type-1 (Th1)-specific immune-responses and inhibits the development of IL-4-producing Th2 cells. J Exp Med 1993;177:1199-204.

9 Lamont AG, Adorini L. IL-12-a key cytokine in immune regulation. Immunol Today 1996;17:214-17.

10 Trembleau S, Penna G, Bosi E, Mortara A, Gately MK, Adorini L. Interleukin12 administration induces T-helper type-1 cells and accelerates autoimmune diabetes in NOD mice. J Exp Med 1995;181:817-21.

11 Segal BM, Shevach EM. IL-12 unmasks latent autoimmune-disease in resistant mice. J Exp Med 1996;184:771-5.

12 Segal BM, Klinman DM, Shevach EM. Microbial products induce autoimmune-disease by an IL-12-dependent pathway. J Immunol 1997; 158:5087-90.

13 Mattner F, Fischer S, Guckes S, Jin SC, Kaulen H, Schmitt E, Rude E, Germann T. The interleukin-12 subunit p40 specifically inhibits effects of the interleukin-12 heterodimer. Eur J Immun 1993;23:2202-8.

14 Hall MA, McGlinn E, Coakley G, Fisher SA, Boki K, Middleton D, Kaklamani E, Moutsopoulos H, Loughran TP, Ollier WE, Panayi GS, Lanchbury JS. Genetic polymorphism of IL-12 p40 gene in immune-mediated disease. Genes Immun 2000;1:219-24.

15 Nerup J, Pociot F, for ECIGS. A genomewide scan for type 1-diabetes susceptibility in Scandinavian families: identification of new loci with evidence of interactions. Am J Hum Genet 2001;69:1301-13.

16 Pociot F, Norgaard K, Hobolth N, Andersen O, Nerup J. A nationwide population-based study of the familial aggregation of type-1 (insulindependent) diabetes mellitus in Denmark. Diabetologia 1993;36:870-5.

17 Lorenzen T, Pociot F, Stilgren L, Kristiansen OP, Johannesen J, Olsen PB, Walmar A, Larsen A, Albrechtsen NC, Eskildsen PC, Andersen OO, Nerup J. Predictors of IDDM recurrence risk in offspring of Danish IDDM patients. Diabetologia 1998;41:666-73.

18 Delepine M, Pociot F, Habita C, Hashimoto L, Froguel P, Rotter J, CambonThomsen A, Deschamps I, Djoulah S, Weissenbach J, Nerup J, Lathrop M, Julier C. Evidence of a non-MHC susceptibility locus in type I diabetes linked to HLA on chromosome 6. Am J Hum Genet 1997:60:174-87.

19 Miller SA, Dykes DD, Polesky HF. A simple salting out procedure for extracting DNA from human nucleated cells. Nucleic Acids Res 1988;16:1215.

20 Bergholdt R, Larsen ZM, Andersen NA, Johannesen J, Kristiansen OP, Mandrup-Poulsen T, Nerup J, Pociot F. Characterization of new polymorphisms in the $5^{\prime}$ UTR of the human Interleukin-1 receptor type 1 (ILIR1) gene: linkage to Type 1 diabetes and correlation to IL-1RI plasma level. Genes Immun 2000;1:495-500.

21 Taneichi M, Horino A, Naito S, Sakurai S, Komuro K, Uchida T. Differential stimulation requirements for IL-12 production among clones of macrophage hybridomas. J Interferon Cytokine Res 1997;17:603-7

22 Goodier MR, Londei M. Lipopolysaccharide stimulates the proliferation of human CD56(+)CD3(-) NK cells: A regulatory role of monocytes and IL-10. $J$ Immunol 2000;165:139-47.

23 Lio D, Danna C, Gervasi F, Scola L, Potestio M, Dilorenzo G, Listi F, Colombo A, Candore G, Caruso C. Interleukin-12 release by mitogenstimulated mononuclear- cells in the elderly. Mech Ageing Dev 1998;102:211-19.

24 Hayes MP, Wang JH, Norcross MA. Regulation of Interleukin-12 expression in human monocytes - selective priming by interferon-gamma of lipopolysaccharide- inducible p35 and p40 genes. Blood 1995;86:646-50.

25 Ma X, Chow JM, Gri G, Carra G, Gerosa F, Wolf SF, Dzialo R, Trinchieri G. The interleukin 12 p40 gene promoter is primed by interferon gamma in monocytic cells. J Exp Med 1996;183:147-57.

26 Karlsen AE, Ronn SG, Lindberg K, Johannesen J, Galsgaard ED, Pociot F, Nielsen JH, Mandrup-Poulsen T, Nerup J, Billestrup N. Suppressor of cytokine signaling 3 (SOCS-3) protects beta-cells against interleukin-1 beta- and interferon-gamma-mediated toxicity. Proc Natl Acad Sci USA 2001;98:12191-6.

27 Spielman RS, McGinnis RE, Ewens WJ. Transmission test for linkage disequilibrium - the insulin gene region and insulin-dependent diabetesmellitus (IDDM). Am J Hum Gen 1993;52:506-16.

28 Davoodi-Semiromi A, Yang JJ, She JX. IL-12p40 is associated with type 1 diabetes in Caucasian-American families. Diabetes 2002;51:2334-6.

29 Dahlman I, Eaves I, Kosoy R, Morrison V, Heward J, Gough S, Allahabadia A, Franklyn J, Tuomilehto J, Tuomilehto-Wolf E, Cucca F, Guja C, lonescuTirgoviste C, Stevens H, Carr P, Nutland S, McKinney P, Shield J, Wang W, 
Cordell H, Walker N, Todd J, Concannon P. Parameters for reliable results in genetic association studies in common disease. Nat Genet 2002;30: 149-50.

30 Johansson S, Lie BA, Thorsby E, Undlien DE. The polymorphism in the 3' untranslated region of IL12B has a negligible effect on the susceptibility to develop type 1 diabetes in Norway. Immunogenetics 2001;53:603-5.

31 Nistico L, Giorgi G, Giordano M, Galgani A, Petrone A, D'Alfonso S, Federici M, Di-Mario U, Pozzilli P, Buzzetti R, Cascino I. IL12B polymorphism and type 1 diabetes in the Italian population-a case-control study. Diabetes 2002;51:1649-50.

32 McCormack RM, Maxwell AP, Carson DJ, Patterson CC, Middleton D, Savage DA. The IL12B 3' untranslated region DNA polymorphism is not associated with early-onset type 1 diabetes. Genes Immun 2002;3:433-5.

33 Eaves IA, Bennett ST, Forster P, Ferber KM, Ehrmann D, Wilson AJ, Bhattacharyya S, Ziegler AG, Brinkmann B, Todd JA. Transmission ratio distortion at the INS-IGF2 VNTR. Nat Genet 1999;22:324-5.

34 Rothe H, Ohara RM, Martin S, Kolb H. Suppression of cyclophosphamideinduced diabetes development and pancreatic Th1 reactivity in NOD mice treated with the Interleukin (IL)-12 antagonist IL-12(p40). Diabetologia 1997:40:641-6.

35 Seegers D, Zwiers A, Strober W, Peña AS, Bouma G. A Taql polymorphism in the $3^{\prime}$ UTR of the IL-12 p40 gene correlates with increased IL-12 secretion. Genes Immun 2002;3:419-23. 